PRZEGLĄD RUSYCYSTYCZNY 2021, nr 3 (175)

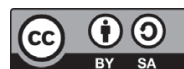

DOI 10.31261/pr.10052

\title{
EWA BIAŁEK
}

Uniwersytet Marii Curie-Skłodowskiej, Lublin

(iD) 0RCID https://orcid.org/0000-0003-3868-5001

\author{
Porządek słów. Gramatyka. Tekst. Styl. Dyskurs, \\ red. T. Kananowicz, A. Klimkiewicz, \\ Wydawnictwo Uniwersytetu Gdańskiego, Gdańsk 2019, 317 s.
}

W 2019 roku ukazała się drukiem jubileuszowa księga dedykowana Profesor Zoi Nowożenowej z okazji 45-lecia pracy naukowej. Monografia zawiera 24 artykuły autorstwa badaczy z ośrodków krajowych i zagranicznych (Gdańsk, Łódź, Olsztyn, Słupsk, Sosnowiec, Szczecin; Kaliningrad, Moskwa, Nowogród Wielki, Nowosybirsk, Ostrawa, Saratów, Uljanowsk). Jubileuszową monografię otwiera wstęp wraz z notą biograficzną oraz opisem dorobku naukowego opracowany przez redaktorów tomu, Tatianę Kananowicz oraz Aleksandrę Klimkiewicz. Zarówno tytuł książki, jak i tematyka artykułów bezpośrednio nawiązują do rozległych zainteresowań naukowych oraz kierunków badań gdańskiej rusycystki w dziedzinie językoznawstwa. Jak wyjaśnia we wstępie Tatiana Kananowicz, monografia jest poświęcona porządkowi słów i porządkowi w słowach (s. 9). W opisie drogi zawodowej zwrócono uwagę m.in. na imponujący dorobek dydaktyczny i konferencyjny, a także wielki wkład Jubilatki w umiędzynarodowienie macierzystej uczelni (Uniwersytetu Gdańskiego) wyrażający się w inicjowaniu umów bilateralnych z uczelniami z Rosji, Czech, Hiszpanii czy Irlandii (s. 18). Wspomagały tę działalność liczne kontakty z naukowcami zagranicznymi. Monografia jest spójna tematycznie i kompozycyjnie (a nawiązując do słowa-klucza „porządek" - jest niewątpliwie uporządkowana), cechuje się staranną redakcją tekstów. Warto odnotować trafną decyzję redaktorów o przygotowaniu dwujęzycznych wersji wstępu, noty biograficznej i dorobku, co pozwala uwzględnić polskiego oraz zagranicznego adresata. Autorzy rozdziałów monografii sięgają do bogatego dorobku publikacyjnego prof. Zoi Nowożenowej, odwołują się też do wspólnych dyskusji naukowych. W artykułach poruszono wiele ważkich we współczesnej lingwistyce zagadnień - gramatyka komunikacyjna, stylistyka, aktualne tendencje rozwojowe języka rosyjskiego, fenomeny w języku i kulturze, badania etnolingwistyczne, badania korpusowe 
i nad dyskursami, język reklamy. Kolejność bloków tematycznych jest przemyślana - od gramatyki poprzez tekst, styl do dyskursu, co koresponduje $\mathrm{z}$ chronologią tematów podejmowanych $\mathrm{w}$ publikacjach Jubilatki w latach 1972-2018 (zob. wykaz prac, s. 25-37).

Część pierwszą zbioru zatytułowaną Gramatyka/Грамматика otwiera artykuł Olgi B. Sirotininy o szyku wyrazów w ruszczyźnie, który, jak dowodzi autorka, nie jest stały ani też zupełnie swobodny (s. 48). Tę konkluzję poprzedza przykładami z tekstów prasowych, ilustrując za ich pomocą na przykład niejednoznaczność sensu zdania w zależności od przyjętego porządku wyrazów, wskazuje prawidłowości w kolejności komponentów połączeń wyrazowych w ruszczyźnie oraz różnice w szyku wyrazów w dialogach ustnych i wypowiedziach oficjalnych ${ }^{1}$. Margarita A. Kormilicyna w pracy Семантические преобразования глагольной лексемы в русском простом предложении (s. 51-58) porusza problem wpływu modelowej semantyki zdania na znaczenie czasownika, które może podlegać desemantyzacji albo leksykalizacji. Jak dowodzi autorka, wzbogacenie semantyki czasownika w zdaniu jest charakterystyczne na przykład dla czasowników percepcyjnych oraz ruchu. W artykule Модусные смыслы изъяснительной конструкции (на примере Я говорю, что...) autorstwa Tatiany I. Stieksowej na materiale tekstowym (Narodowy Korpus Języka Rosyjskiego) pokazano funkcjonowanie i znaczenie konstrukcji typu $Я$ говорю, что w zdaniach złożonych. Jej użycie bywa uwarunkowane potrzebą doprecyzowania zamiaru komunikacyjnego, podkreślenia punktu widzenia mówiącego, kategoryczności wypowiedzi i in. (s. 59-67). O modelu zdania w aspekcie teoretycznym (Moдель предложения в синтаксических теориях) pisze Tatiana Kananowicz (s. 68-77). Po przeglądzie teorii składniowych (m.in. w dorobku Galiny A. Zołotowej czy Niny D. Arutiunowej) autorka omawia rozumienie modelu zdania w monografii Zoi Nowożenowej Русское глагольное предложение: структура и семантика $(2001,2016)^{2}$. Artykuł zamyka konkluzja o użyteczności tej teorii w badaniach nad tekstem, stylem, dyskursem (s. 75).

${ }_{1}$ Szyk w dialogach potocznych rosyjska badaczka szczegółowiej omawia we wcześniejszych pracach, np.: О.Б. Сиротинина, Всё, что нужно знать о русской речи. Пособие для эффективного общения, Книжный дом «Либроком», Москва 2010, с. 88-91.

2 Monografia przedrukowana w Rosji w 2016 r. doczekała się recenzji przygotowanej przez rosyjskiego lingwistę: Е.А. Казак, Новоженова З.Л., Русское глагольное предложение: структура и семантика. - М.: Ленанд, 2016. - 256 с., Социальные и гуманитарные науки. Отечественная и зарубежная литература. Cер. 6: Языкознание. Реферативный журнал, №4, ИНИОН, Москва 2017, с. 136140, https://cyberleninka.ru/article/n/2017-04-038-novozhenova-z-l-russkoeglagolnoe-predlozhenie-struktura-i-semantika-m-lenand-2016-256-s (15.09.2020). W recenzji podkreślono m.in. wykorzystanie w monografii różnorodnej podstawy materiałowej pozwalającej na wychwycenie wspólnych mechanizmów językowych dla tekstów o różnych cechach stylistycznych (Tamże, s. 138). 
Zagadnienie normalizacji języka kaszubskiego porusza Dušan-Vladislav Paždjerski (s. 78-86). W publikacji, która, jak zauważa we wstępie jej autor, stanowi rozwinięcie rozmów prowadzonych z gdańską badaczką na temat kaszubszczyzny (s. 78), przybliżono misję oraz strukturę Rady Języka Kaszubskiego (lata 2007-2016), jej starania zmierzające do uporządkowania terminologii stosowanej w tym języku.

$\mathrm{W}$ artykułach zamieszczonych w drugiej części tomu naukowcy odnoszą się do pojęcia tekstu, gatunku oraz strategii komunikacyjnych w tekście. W pracy Doroty Żyłki i Bogusława Żyłki Od Bachtina do Austina omówiono doktrynę lingwistyczną Ferdinanda de Saussure'a oraz jej odzwierciedlenie w późniejszych teoriach lingwistycznych (s. 89-102). Autorzy poszukują obecności pojęć langue i parole w koncepcjach Grigorija Winokura, Michaiła Bachtina, Ludwiga Wittgensteina, Bronisława Malinowskiego oraz Johna Langshawa Austina, dokonują też porównania pojęć „akt mowy” i „gatunek mowy" w odniesieniu do teorii szwajcarskiego lingwisty. Henryk Fontański na materiale utworu Bieguni Olgi Tokarczuk oraz jego rosyjskiego przekładu przeprowadza lingwistyczną analizę obrazów pamięci tworzonych przez zróżnicowane zabiegi narracyjne, z aktywnym zastosowaniem wielości form czasownikowych. W charakterze narzędzia interpretacyjnego tekstów posłużono się gramatyką komunikacyjną (s. 103-113). Do tekstotwórczej roli kategorii modalności nawiązuje rosyjska badaczka Swietłana S. Waulina w artykule Текстообразующая роль экспликаторов субъектно-модальных значений в рассказах А. П. Чехова (s. 114-121). Językowe środki wyrazu znaczeń konieczności, możliwości są wykorzystywane w opowiadaniach Czechowa, współtworzą wyrazisty językowy i psychologiczny portret ich bohaterów. Analizę przeprowadzono na materiale kilku utworów, w tym noweli Dama z pieskiem. Artykuł Michaiła J. Fiedosiuka Эпистолярный жанр русской речи до и после Петра I (s. 122-131) jest poświęcony kształtowaniu się norm gatunku epistolarnego w języku rosyjskim oraz związku tego gatunku z kulturą. Analizując kompozycję „bieriestianych gramot” i późniejszych pism urzędowych, autor zauważa dwudzielność struktury gatunku epistolarnego oraz stabilność jego wzorca utrzymującą się przez kilka stuleci aż do epoki cara reformatora. Małgorzata Kudlik-Jędruch omawia książkę, która zajęła stałe miejsce w kanonie lektur literatury masowej (Феномен Гарри Поттера как явления массовой культуры). Powieść doczekała się licznych przekładów, w tym na języki rzadkie: afrikaans, grenlandzki, urdu. Autorka dzieli się także spostrzeżeniami na temat tajników pracy polskiego tłumacza książek z tej serii, Andrzeja Polkowskiego.

Część trzecią monografii, którą poświęcono problemom stylistyki, otwiera artykuł Tatiany W. Szmielowej (s. 147-156), w którym mowa o stylistycznym potencjale imienia odojcowskiego. Na konkretnych przykładach autorka licznych prac onomastycznych wskazuje, że patronimik to nie tylko element etykiety językowej i jednostka identyfikująca osoby w kulturze rosyjskiej. Ten model derywacyjny bywa stosowany w tworzeniu nominacji 
zwierzęcych bohaterów literackich (np. кот Котофеич), hydronimów (rzeka Дон Иванович) ${ }^{3}$, obiektów handlowych, a także leksyki nacechowanej pejoratywnie (олигарх олигархович) i innych okazjonalizmów (Доклад Докладыч). Pojęcia stylu i stylistyki w tradycji rosyjskiej oraz czeskiej omawia Zdeňka Nedomová. W oparciu o istniejące pary odpowiedników terminologicznych porównuje ona tradycje stylistyczne oraz aktualne tendencje rozwojowe tej dziedziny w obu krajach. Poza paralelizmem kierunków i odpowiadających im terminów autorka odnotowuje również odmienność w rosyjskim oraz czeskim instrumentarium terminologiczno-pojęciowym (np. стилистика кодирования, s. 160). Nasima S. Szarafutdinowa analizuje zapożyczenia obcojęzyczne $\mathrm{w}$ angielskiej i rosyjskiej terminologii ekonomicznej oraz prawniczej. Autorka formułuje wniosek, że zapożyczenie ułatwia proces internacjonalizacji systemów terminologicznych w różnych językach (s. 171). Grażyna Lisowska w artykule poświęconym problemowi obniżenia standardu językowego w komunikacji publicznej (s. 177-185) podejmuje problem liberalizacji norm w rosyjskim języku literackim, w wyniku której nasilił się proces interakcji literackich stylów funkcjonalnych oraz języka potocznego i żargonów. W kontekście kolokwializacji języka nawiązuje też do aktualnego problemu feminatywów. Aleksandra Klimkiewicz w artykule dotyczącym nauczania języka rosyjskiego dla celów komunikacji specjalistycznej podkreśla potrzebę takiego kształcenia na studiach rusycystycznych, przedstawia teoretyczny zarys leksykalnych minimów, zwraca uwagę na ich nasycenie terminologią i podejście sytuacyjno-komunikacyjne (s. 186-198). $\mathrm{O}$ kliszach językowych $\mathrm{w}$ przekładzie prawnym pisze Olena Yegorova (s. 199-209). Autorka konfrontuje ekwiwalenty zastosowane w przekładzie polskiej Ustawy o podatku od towarów i ustug na język rosyjski z danymi słownikowymi, tekstowymi, wskazuje też pary ekwiwalentów jako propozycje dla leksykografii.

Osiem artykułów weszło do czwartego bloku tematycznego, który został poświęcony nowszemu nurtowi badań - dyskursowi i analizie dyskursywnej tekstu. Aleksander Kiklewicz zgłębia dyskurs wizerunkowy, który ma na celu „kreowanie lub kultywowanie wizerunku jednostki lub instytucji” (s. 214). Zgodnie z zapowiedzią w tytule publikacji, analizie poddano informację semantyczną w postaci: 1) informacji egzystencjalnej, 2) informacji o właściwościach, 3) informacji wartościującej. Konotacja wartościująca frazematycznych struktur tekstowych $\mathrm{w}$ dyskursie medialnym stała się obiektem badań Alicji Pstygi (s. 227-234). Autorka na wstępie zaznacza, że dominującym tematem $\mathrm{w}$ dyskursie medialnym jest polityka, uwagę tę potwierdza wyekscerpowanym z prasy zestawem jednostek wartościujących różne fakty

3 Taki zabieg Korniej Czukowskij zastosował $\mathrm{w}$ wierszowanym poemacie dla dzieci Крокодил (1915) - Крокодил Крокодилович. Strofa pierwsza: Жил да был / Крокодил. / Он по улицам ходил, / Папиросы курил, / По-турецки говорил, / Крокодил, Крокодил Крокодилович! 
i osoby. Jak pokazuje badanie, w tekstach struktury te są poddawane modyfikacjom, aktualizacjom, mogą być wyrazistym nośnikiem wartościowania, z czasem niektóre z nich podlegają utrwaleniu, uskrzydleniu. Kolejny artykuł zatytułowany Magia miłosna roślin w Stowiańszczyźnie. Wybrane zagadnienia autorstwa Ewy Komorowskiej przenosi czytelnika w świat magicznych roślin i zaklęć z nimi związanych (s. 235-250). Badaczka przybliża współczesnemu odbiorcy dawne rytuały z wykorzystaniem roślin afrodyzyjnych (lubczyk, przestęp, nasięźrzal, rozmaryn, ruta, mięta i in.), zwraca uwagę na obiegowe nazwy niektórych ziół („małżeńskie kwiecie”, „rączki szczęścia" $i$ in.) oraz związek między przypisaną tajemną mocą a aromatem czy kształtem. Regina Wyżkiewicz-Maksimow na materiale danych słownikowych oraz tekstów kultury porównuje obraz osy i pszczoły w języku oraz kulturze polskiej i serbskiej. Analizę rozpoczyna od zbadania etymologii obu nazw oraz konotacji przypisanych owadom w kulturze antycznej i chrześcijańskiej. W toku badań stwierdza zarówno antynomię obrazów tych owadów, jak i podobieństwo ich postrzegania w danych językach. Z kolei Danuta Stanulewicz przeprowadza analizę znaczeń przymiotnika „brzoskwiniowy” metodą korpusową (s. 262-275). Korzystając z narzędzi informatycznych (NKJP, PELCRA), ustala rozkład znaczeń i kolokaty nazwy barwy. Autorka zwraca uwagę na niejednolitość opisu koloru brzoskwini w tekstach i słownikach. Żanna Sładkiewicz w artykule Принцип трех «С» в эпатажной социальной рекламе: секс, смерть и смех porusza zagadnienie przełamywania tabu, szokowania w reklamie społecznej, która jest skutecznym narzędziem w kształtowaniu systemu wartości i kreowania zachowań społecznych (s. 276-294). Badaczka podkreśla dwubiegunowość tematyki reklamy: sfera życia i miłości (Eros) oraz sfera śmierci, agresji, przemocy (Tanatos). Urszula Patocka-Sigłowy oraz Monika Rzeczycka poddają analizie wypowiedzi szefa rosyjskiego MSZ pod kątem obecności w nich środków wartościujących (ocena pejoratywna). Odnotowane przez autorki językowe sposoby eksplikacji oceny negatywnej są różne, wśród nich: partykuły, przymiotniki, frazeologizmy oraz elementy słowotwórcze. Obiektem zainteresowań Marcina Trendowicza stał się fenomen legendarnego agenta Stirlitza w kulturze rosyjskiej (s. 305-317). Autor poświęca uwagę wykorzystaniu antroponimu bohatera literackiego i filmowego Stirlitz jako nazwy rozpoznawalnej, kulturonośnej (ros. прецедентное имя) w dyskursie wirtualnym, kulinarnym i reklamowym. Okazuje się, że ta nazwa własna ma szerokie zastosowanie: jako nominacja wirusa, ciasta czy kawy. Obraz agenta oraz antroponim, zdaniem autora, są wartościowane pozytywnie.

Niekwestionowaną zaletą książki Porządek słów. Gramatyka. Tekst. Styl. Dyskurs jest nie tylko szeroki przekrój podjętych tematów, ich atrakcyjność poznawcza, ale i zaangażowanie w naukową dyskusję na łamach tomu przedstawicieli różnych ośrodków oraz szkół badawczych z kraju i zza granicy. Do atutów monografii należy zaliczyć także wzmiankowaną już oryginalną koncepcję kompozycji pracy. Książka tym samym daje ogląd kierun- 


\section{RECENZJE}

ków rozwoju zainteresowań badawczych prof. Zoi Nowożenowej, a szerzej zaś - pokazuje różnorodność badań językoznawczych oraz dynamikę ich rozwoju, zapoznaje ze współczesnymi tendencjami metodologicznymi i preferencjami tematycznymi. Monografia przybliża zarazem rosyjskie szkoły badawcze, integruje środowisko slawistów.

\section{REFERENCES}

Kazak, Ye.A. "Novozhenova Z.L., Russkoye glagol'noye predlozheniye: struktura i semantika. Moskva: Lenand, 2016." Sotsial'nyye i gumanitarnyye nauki. Otechestvennaya i zarubezhnaya literatura. Ser. 6: Yazykoznaniye. Referativnyy zhurnal, Moskva: INION, 2017, no. 4: 136-140 [Казак, Е.А. Новоженова 3.Л., Русское глагольное предложение: структура и семантика. Москва: Ленанд, 2016.” Социальные и гуманитарные науки. Отечественная и зарубежная литература. Сер. 6: Языкознание. Реферативный журнал. Москва: ИНИОН, 2017, по. 4: 136-140, <https://cyberleninka.ru/article/n/2017-04-038-novozhenova-z-l-russkoe-glagolnoe-predlozhenie-struktura-isemantika-m-lenand-2016-256-s (15.09.2020)>].

Sirotinina, Olga B. Vsyo, chto nuzhno znat' o russkoy rechi. Posobiye dlya effektivnogo obshcheniya. Moskva: Knizhnyy dom "Librokom", 2010: 88-91 [Сиротинина, Ольга Б. Всё, что нужно знать о русской речи. Пособие для эффективного общения. Москва: Книжный дом “Либроком”, 2010: 88-91]. 